\title{
Global Tourism New Volatility, Old Statistics
}

\author{
Alberto Corti ${ }^{*}$
}

\begin{abstract}
In 2015 the scenario of global tourism has radically changed. The new scenario has shifted from the approach of the foregoing 'closed-circuit' international tourism flows and the creation of different development centres of the tourism economy in the world taking over the global business that was previously in the hands of Europe and North America. The globalisation of tourism is unavoidable and, in many respects, positive. The creation of new tourist destinations and new countries generating outgoing tourism in different continents and areas worldwide determined, in those places, the growth of operators and the creation of tourist value-added chains that have gradually increased their strength and expansion. Therefore, in a global market of international tourism flows, routes followed by tourist expense and value added generated by such expense can differ considerably from the route that is physically followed by the tourism flow itself.
\end{abstract}

Keywords: Global Tourism; Tourism Flows; Destination Countries; Holiday; Package Tours

\section{Tourism Flows by Destination Countries}

In 1970 Italy ranked first in the world for international tourist arrivals and corresponding receipts. Today it ranks fifth among countries receiving a larger number of international flows and seventh in the ranking for receipts. But does the comparison of such scenarios make any sense?

As a matter of fact, these are two completely different worlds, in terms of both absolute values and composition of the competitive structure. Tourism in 2015 shows all the features of a globalized phenomenon whereas 45 years ago tourism was not really as such.

In 1970, starting from absolute values, 159,690,000 people crossed national borders for tourism out of a global population of 3,5 billion (less than 5\%). The total expenditure for international tourism accounted for USD 17.9 billion. Italy ranked first and was followed, in order, by Canada, France, Spain and the United States. Together with these four countries, Italy received $43 \%$ of the international flows of arrivals worldwide. These countries were followed in the ranking by Austria, Germany, Switzerland, Yugoslavia and the United Kingdom, and with their arrivals a share of $65 \%$ was reached. In 2015 international tourists were

*Head of Confcommercio Tourism Sector (a.corti@ confcommercio.it)

Edited by: ISTEI - University of Milan-Bicocca

ISSN: 1593-0319

Corti, A. (2016). Global Tourism New Volatility, Old Statistics, Symphonya. Emerging Issues in Management (symphonya.unimib.it), 1, 25-30. 
$1,184,000,000$ out of a world population of 7.4 billion (16\%). Expenditure for international tourism was slightly lower than USD 1,300 billion and in the ranking of arrivals, France, the Unites States, Spain and China were ahead of Italy, making up - in the aggregate and including Italy - a market share of $28 \%$. These countries were followed by Turkey, the United Kingdom, Germany, Russia and Mexico and with their arrivals $42.5 \%$ of the overall international tourism flows was reached.

Such data show a remarkable progression in the flows and in the importance that international tourism acquired in a bit less than fifty years. As a matter of fact, tourism shifted from an essentially elitist phenomenon to a widespread behaviour, from an almost pioneering stage to the current stage of strong development and in some instances the development has reached maturity.

In the ' 70 s the concentration of flows by destination countries was undoubtedly higher, in all respects. As described above, in addition to the fact that $65 \%$ of all international flows was concentrated in the 10 top destinations (compared to $42.5 \%$ in 2015), the great majority of big players was in Europe: only Canada and the United States were the exception to the rule, being the only two non-European countries among the 10 countries totalling the highest number of international arrivals. And it is to be pointed out that these two countries are among the most populous in the world and that they share, inter alia, a direct border stretching for 8,900 kilometres, being the longest border worldwide. Therefore, it is not misleading to assume that most international arrivals of each of these two countries, that, on the other hand, at that time already recorded a limited presence of passports among their respective residents, were of mutual origin, hence neighbouring.

$\square$ In 2015, six European countries (if Russia is included) are listed in the destinations' top ten but, above all, new continents are coming into play. In addition to North America, with the United States and Mexico, Asian destinations are entering peremptorily the touristic arena: China and Turkey - with China ranking forth - totalling almost 57 million of international arrivals. This is an undoubtedly wide-ranging competitive scenario, in which new players carry out their activities creating new meeting points between demand and supply, new marketplaces, that are at different stages of their life cycle in the tourism sector.

Let's get back briefly to the '70s. It was a world where the exchange of international tourism flows looked a lot like a closed circuit. Not only with regard to the exchanges of flows of vicinity between the United States and Canada, as mentioned above, but also in Europe, where there were the most important tourist destinations worldwide ( 8 out of 10) as well as the biggest concentration of demand. In short, international tourism destinations for Europeans were in Europe and for North Americans in North America, whereas the intercontinental touristic traffic was essentially limited to these two macro areas: North Americans in Europe and Europeans in North America. But it is to be pointed out that, at that time already, other travelling routes were developing as well. By way of illustration, at the end of the '70s Italians discovered Kenya (and especially Malindi) as tourism destination, with the starting of charter flights. However, these flows are residual in terms of number of arrivals and are only slightly more substantial in terms of expense. Especially at that time intercontinental travellers had to overcome the 
barrier of the high cost of air transport and they had and still have today a spending power for the tour and during it that, on average, is higher than the spending power of tourists travelling in neighbouring countries or in the same area.

In 2015 the scenario has radically changed. If the first ten destinations of international tourism in the world are those already specified, with regard to countries generating outbound flows - based on the travelling expense of their residents - the first 10 are, in order, China, the United States, Germany, the United Kingdom, France, Russia, Canada, Italy, Australia and Saudi Arabia, namely five European countries (including Russia), two North American countries, one country in the Middle East, one in the Far East and one in the Pacific area.

This entails a shift from the approach of the foregoing 'closed-circuit' international tourism flows and the creation of different development centres of the tourism economy in the world taking over the global business that was previously in the hands of Europe and North America. There is a simple reason for this. When, for a number of factors, such as the internal economic development, the increase in the average spending power of its citizens, the progressive spreading of the travelling culture and the good international diplomatic relations, a country starts to generate outbound touristic flows, usually its first destinations are neighbouring countries or countries in the same area. In the same way as the first destinations abroad for Italians were neighbouring countries such as France, Switzerland, Austria and the then Yugoslavia, and subsequently in Europe and in the whole Mediterranean area, in Africa and outside Europe, the same happened for the Chinese, Russians and Saudi Arabians who have entered the outgoing tourism world in more recent years. The first destinations - that are still the most popular today - are countries such as Korea, Thailand and Japan and cruises in the Indian Ocean. Russians started travelling at first in the countries of the former USSR having a milder climate and then in Turkey and Europe and, more recently, reaching the sun and sea destinations of the Red Sea and in Thailand. Saudi Arabians discovered first the Middle East and Egypt and then they rapidly started to travel all over the world. Therefore, at least during the first stage, the development of outgoing tourism of a specific country entails the growth of the tourist services in neighbouring countries and in the same area, thus creating in these places a new market - intended as the meeting point between demand and supply - a new tourism 'centre' that develops and hence enters the competition with those already existing. Therefore, if in the "70s Italy was the first tourist destination and the one in which international tourists were spending more in a world where tourist circulation was almost entirely intra-European, intra-North American and between North America and Europe, it is not difficult to justify the fact that today, after almost fifty years, it ranks fifth for arrivals and seventh for currency receipts, with the latter being a clear 'statistical false' with the Macau island ahead of Italy. Covering an area that is one third of the Bracciano lake, the Macau island records as tourist receipts all the expenses that Chinese gamblers - arriving from Hong Kong in a few minutes by high-speed ships - make in the large number of gambling houses in Macau. Today, for instance in South America, the Middle East, the Pacific Area, the Far East and in Southern Africa, a number of local tourist centres have been created in competition with traditional tourist centres in Italy and throughout Europe and they are inevitably acquiring from the latter part of their market share. 
The litmus test of the foregoing is the composition of tourist arrivals in Italy from abroad broken down by country of origin. In 1970 the first 10 countries of origin were, in order, Germany, the United States, France, the United Kingdom, Switzerland, Austria, the Netherlands, Yugoslavia, Belgium and Denmark. Their sum totalled $11,028,736$ arrivals, equal to $87 \%$ of $12,692,551$ arrivals that at that time was the total number of international arrivals in Italy in hotels and in accommodations other than hotels.

In 2015 Germany ranked first for arrivals, followed, in order, by the United States, France, the United Kingdom, China, Switzerland, Austria, Russia, the Netherlands and Spain, totalling 35,619,722 international arrivals out of the total number of 53,029,659 arrivals, equal to $67 \%$. Therefore, if in 45 years the composition of our 'top ten' for international tourist arrivals has changed from nine European countries and one in North America to eight European countries (including Russia), one of North America and one in Asia, the difference refers mainly to the concentration level.

\section{The Globalisation of Tourism. Effects on GDP and Value Added}

This is the globalisation of tourism that is unavoidable and, in many respects, positive. However, in addition to the effects of the foregoing process there are also others that over the years brought to the creation of new tourist markets in the world. Other effects are to be taken into consideration, that are not perceived immediately and are still eluding the more common reporting data - arrivals, attendance and expense - exerting an influence on the economy of the countries that generate and receive the international flows, and in some instances also of third countries, with a more significant impact. It is the case of the actual contribution made by the international tourism to the GDP of the destination country, and particularly of the travelling expenses borne by these tourists.

The creation of new tourist destinations and new countries generating outgoing tourism in different continents and areas worldwide determined, in those places, the growth of operators and the creation of tourist value-added chains that have gradually increased their strength and expansion. Such chains are made up of different components, such as: accommodation facilities - hotels, apartment hotels, holiday villages, resorts, camping sites and, more recently, Bed \& Breakfast, holiday rentals and the like; operators for local transport and transfers; operators dealing with catering and entertainment; tour guides; operators of the cultural sector in charge of museums and areas of historical and archaeological interest; the intermediaries - the so-called incoming tour operators and travel agencies organizing, in tourist destinations, short trips and excursions as well as the whole package of the above-mentioned services, offering them, already arranged, to the intermediaries organising the flows in the countries of origin; means of transports (by air, railway, road and sea) enabling touristic flows to move from one country to another, and finally the network for the promotion and distribution to the public of the foregoing tourist services. If some of these components, such as - for instance hotels and accommodations other than hotels or the distribution of tourist services to end customers, as far as 'traditional' distribution is concerned, must have operational offices in the country of origin and of destination, other components 
can be based both in one country or the other, or even in a third country. Air carriers represent a good example for flows using this means of transport. A Chinese tourist who buys in his country a holiday in Italy can reach our country with a Chinese airline or with an Italian one that operates direct flights with China or with an English, German or French airline, in such instance - staying for a very short time to change the flight or deciding to spend some days in the United Kingdom, in Germany or in France. Considering that, at least in the segment of package tours, on average, the cost of air transport accounts for $39 \%$ of the final price paid by the customer for the purchase of the package tour itself, the choice of the foregoing three options of air transport entails the transfer of more than one third of the expense of the end customer to the GDP either of the country of origin, of the country of destination or even of a third country.

But there are many more and more complex scenarios. By way of illustration, other two cases will be described. An Italy-based hotel managed by a foreign company (for example a major hotel chain) will transfer in the country where the management company is based part of the added value from the sale of its services to customers, made either directly or through an intermediary. A Russian tourist buying the package tour or the individual tourist services necessary for his holiday in Italy from a Dutch portal transfers in the GDP of the Netherlands a percentage of his expense that is at least equal to the mark-up - about $12 \%$ - that a Russian tour operator would have transferred in the GDP of this country if the customer had asked him such services5.

Therefore, in a global market of international tourism flows, routes followed by tourist expense and value added generated by such expense can differ considerably from the route that is physically followed by the tourism flow itself. This is due to the fact that, with their behaviour, tourists are inevitably a source of costs for the community, especially for the destination countries of their tours that must provide security services and must remedy the effects of the anthropic impact that tourists exert on the places they visit. The careful analysis of the actual contribution of such flows to the added value and to the GDP of the destination countries, irrespective of their number or of the number of nights spent in the destination, plays an essential role in order to carry out a proper costs-benefits analysis.

However, these data often are not available or are not gathered by international and national tourist sources that are more widespread and used in the tourism sector. In order to provide a picture of the scale of the phenomenon, a study carried out in 2013 taking only into account organised tourism flows of foreign origin having Italy as destination in the form of package tours - that in 2013 accounted for $18.8 \%$ of total expense of foreign tourists for the purchase of tours to our country provided the following data: out of a total spending of EUR 5.703 billion (recorded for package tours having Italy as destination bought by foreign tourists in 2012) $47.1 \%$ was destined to the Italian tourism chain contributing to the national GDP, even if this figure is gross of the value of imports necessary for rendering the services required; the remaining $52.9 \%$ went to one or more foreign tourism chains of the country of origin and/or of third countries .

However, there figures changed significantly according to the country of origin of the tourism flow taken into account: the percentage of the Italian tourism chain for instance amounted to $54.4 \%$ of the expense for the purchase of the tours by German tourists, to $58.2 \%$ for Russian tourists, to $47.9 \%$ for US tourists and to $49.3 \%$ for 
Japanese tourists. Changes in such percentages were mainly due to the impact exerted on the price of the package tour by the transport cost (whose increase determined the increase of the foreign tourism chain due to the substantial weakness of the system of Italian direct air connections to tourists' main countries of origin) and of the accommodation chosen (whose increase determined the increase of the Italian tourism chain).

\section{Bibliography}

Assaf, A. G., \& Josiassen, A. (2012). Identifying and Ranking the Determinants of Tourism Performance: A Global Investigation. Journal of Travel Research, 51(4), 388-399. http://dx.doi.org/10.1177/0047287511426337

Bellini, N. (2015). Smart Specialisation in Europe: Looking Beyond Regional Borders. Symphonya. Emerging Issues in Management (symphonya.unimib.it), 1, 22- 29. http://dx.doi.org/10.4468/2015.1.03bellini

Brondoni, S.M. (2014). Global Capitalism and Sustainable Growth. From Global Products to Network Globalisation. Symphonya. Emerging Issues in Management (symphonya.unimib.it), 1, 10 - 31. http://dx.doi.org/10.4468/2014.1.02brondoni

Brondoni, S.M. (2011). Global Networks, Knowledge Management and World Cities. Symphonya. Emerging Issues in Management (symphonya.unimib.it), 1, 7-18. http://dx.doi.org/10.4468/2011.1.02brondoni

Jurigová, Z. (2016). Tourism: New Destination of Global Business Environment. International Advances in Economic Research, 22(3), 351-352. http://dx.doi.org/10.1007/s11294-016-9584-x

Manente, M. \& Minghetti, V. (2013). Il Turismo Organizzato Incoming Dalla Spesa Del Turista All'analisi Della Filiera, All'individuazione Delle Aree Critiche, Confturismo, Confcommercio, CISET, University Ca' Foscari - Venice.

Salvioni, D.M. \& Bosetti L. (2014). Sustainable Development and Corporate Communication in Global Markets. Symphonya. Emerging Issues in Management (symphonya.unimib.it), 1, 32 - 51. http://dx.doi.org/10.4468/2014.1.03salvioni.bosetti

UNWTO (2016). Tourism Highlights. 2016 Edition. Madrid.

UNWTO (2016). World Tourism Barometer, 14 May 2016.

Wu, C. (2016). Destination loyalty modeling of the global tourism. Journal of Business Research, 69(6), 2213-2219. http://dx.doi.org/10.1016/j.jbusres.2015.12.032 